\title{
Teachers' perception of grammar: isolated or integrated?
}

\author{
Nurenzia Yannuar \\ State University of Malang \\ Jl. Semarang 5 Malang, East Java \\ nurenzia.y@gmail.com
}

\begin{abstract}
Explicit teaching of grammar, despite being the most popular in Asia, is not the only key to the mastery of English. There are different successful approaches to the teaching of grammar, which might be interesting to explore. Aside from the famous traditional grammar teaching, there are others such as communicate approach to grammar teaching, isolated and integrated approach, as well combination of both isolated and integrated grammar teaching. The current study is interested in exploring the different views on grammar teaching as well as understanding how English teachers perceive grammar teaching itself. The result of the recent study has been able to give insights that grammar is still considered important by a group of people that has been trained in a specific course of grammar teaching (pedagogical grammar class). Recognizing the standpoint of a group of people who will be assigned the role of teachers is important, because it suggests how grammar will be taught in future language classrooms.
\end{abstract}

\section{INTRODUCTION}

\section{T1. Introduction}

Despite the swing of the grammar pendulum in western countries, most EFL teachers in Asia conserve their respects towards the explicit teaching of prescriptive grammar.Learning English in such situation, English teachers in Asia tend to perceive grammar as the key to the mastery of the language; and for them, a successful language classroom would be one that emphasizes grammar. When these teachers come to America for further studies on the Teaching of English as a Second Language (TESOL), they realize that grammar is taught differently in different parts of the world. Grammar; however, has also been perceived differently in different eras. Based on the situation explained above, the current study is interested in exploring the different views on grammar teaching as well as understanding how English teachers perceive grammar teaching itself. In doing so, the first part of the paper discusses isolated and integrated approach in the teaching of grammar, while the second part focuses on a small-scale research of English teachers' perceptions towards both approaches.

\section{Literature Review}

Current research in Second Language Acquisition (SLA) mainly debates on the conceptual reconsideration of grammar teaching. The aim of this literature review is to focus on the current issues of grammar teaching in communicative language classrooms, as well as to find out teachers' perceptions about the teaching of grammar itself. In order to do so, the review attempts to answer several questions as follows: 
(1) What is the scholarly debate on the necessity of teaching grammar in SLA classrooms? (2) What are the two different approaches to integrate form-focusedinstruction(FFI)intoa

communicative classroom? (3) Which methods of grammar teaching are preferred by teachers? The questions aim to help clarify recent issues in teaching grammar as part of communicative language teaching methods and give better understanding of how English teachers actually view grammar teaching.

\subsection{Traditional View of Grammar}

Traditionally, language teaching views grammar as the most important foundation of acquiring second languages. According to Krashen (1992), "not long ago, it was thought that formal grammar instruction was the only means of developing second language competence" ( $p$. 409). Krashen goes on to argue that focusing on the teaching of grammar will not ultimately improve students' second language proficiency because it will only function as a monitor. Nassaji and Fotos (2004) explained that many researchers now believe that "formal grammar lessons would develop only declarative knowledge of grammar structures, not the procedural ability to use forms correctly" (p. 127). Currently, most scholars agree that a second language is most easily acquired when grammar is taught in a natural learning environment (Spada\&Lightbown, 2008). 2.2 The Communicative Approach in Grammar Teaching

In order to provide students with natural learning environment needed, a new teaching method was introduced in the 1970s.

Communicative language teaching (CLT) invites students' interaction while also focusing on meaning. As part of CLT, content-based instruction (CBI) is also designed to focus on content and disregard several language features and patterns (Spada\&Lightbown, 2008). However, linguists find that a complete meaning-only instruction is not successful in most language teaching situations.

Nassaji and Fotos (2004) state that there are four rationales for this reconsideration. First, there is confusion about the hypothesis that language learning is an unconscious activity. They base their arguments on the findings of Skehan (1998) and Tomasello (1998) that students have difficulties recognizing specific forms and meaning at the same time; therefore, instruction focusing on form is needed. Second, there is evidence that grammar teaching can prepare for the next phase of language competence. Third, former research shows that meaning-focused teaching approach leads to a lack of grammar accuracy. Fourth, a number of classroom studies show that grammar focus has positive result on the development of certain language forms.

Spada and Lightbown (2008) refer to this situation as where "both research and teaching experience have led to a growing consensus that instruction is most effective when it includes attention to both form and meaning" (p. 184). In other words, the main discussion about grammar in second language area is no longer on whether grammar should be taught or not, rather, how grammar can be integrated within CBI and CLT. Laufer (2006) proposes that one way to do this is by having form-focused instruction (FFI), which Spada and Lightbown (2008) believe is able to help students concentrate on "sounds, words, and sentences" of the second language (p. 182).

Grammar teaching within a communicative approach is often seen as a binary system since there are two approaches that are offered by most SLA scholars. Long (1991) is the first to distinguish focus on forms from focus on form. The former conveys the idea that grammar should be taught systematically, while the latter is "an instruction that overtly draws students' attention to linguistic elements as they arise incidentally in lessons whose overriding focus is on meaning or communication" (Long, 1991, p. 45). In discussing the two types of instruction, scholars often use different terminologies that might be confusing. Spada and Lightbown (2008) mention that Johnson (1982) distinguishes unificationist teaching from separationist teaching. Hulstijn (2003) refers to them as intentional and incidental learning, Nassaji (2000) mentions them as by design and by process teaching, while DeKeyser and Ellis (2006) use explicit and implicit terms. However, this current research uses the term isolated and integrated $\mathrm{FFI}$ in reference to Spada and Lightbown (2008).

\subsection{Integrated Grammar Teaching}

Integrated FFI presents language form within a communicative situation. It is not uttered explicitly; rather, teachers are drawing the student' attention to the rules unconsciously (Ellis, 2006). 
Integrated FFI treats language learners as language users, meaning that they use language as a tool in a situation similar to real world. Students are encouraged to use words as tools when completing their tasks (Ellis as cited in Laufer, 2006). Spada and Lightbown (2008) state that integrated FFI plays an important role in improving students' communicative skills as they express meaning. Teachers may not rely on this type of instruction in order to change students' language competence; however, they can use it to help students understand detailed features of the second language.

In their article, Spada and Lightbown (2008) emphasize that integrated FFI is supported by theoretical and experimental research. Based on a theoretical hypothesis of transfer appropriate processing (TAP), it is predicted that learners will easily access language features they learned through similar situations. If they would use it in real life situations, then the best way to teach the features is by integrating them in a communicative classroom. In addition to that, several studies in particular classrooms have demonstrated that integrated FFI is successful.

\subsection{Isolated Grammar Teaching}

As cited in Laufer (2006), Ellis argues that

Focus on Forms treats students as the learners of a language, and language is merely the object of their study. Isolated grammar is often related to traditional grammar teaching. But Spada and Lightbown (2008) perceive it differently. According to them, "isolated FFI is attention to form in separate lessons that occur within a program that is primarily communicative in orientation" (p. 193). This means that isolated and integrated grammar is complementary to each other, and cannot be seen as two contrastive approaches. This supports Doughty and Williams' (1998) proposal that both approaches "are not polar opposites in the way that form and meaning have often been considered to be" (p. 4).

2.5 Combining Integrated and Isolated

\section{Grammar Teaching}

It is not an easy task for teachers to decide which method to be used in teaching grammar in a communicative classroom. There are several factors to be considered in order to achieve the best result. Spada and Lightbown (2008) note that L1 influence is one major factor that affects the use of FFI. According to them, isolated FFI is important to distinguish L2 features from L1 when the students share the same difficulties. This type of instruction will help them notice the differences and prevent them from sharing the same mistakes. Teachers are challenged to use a proactive approach, meaning that they must recognize the common mistakes shared by their students and put them in the syllabus or curriculum (Doughty \& Williams, 1998).

Spada and Lightbown (2008) list another eight factors that can affect the application of both FFI: (a) Salience in the input, isolated FFI will help emphasize simple rules which may not be noticeable during verbal communication; (b) input frequency, the same type of FFI is needed to increase the input of particular language features that might be missing during $\mathrm{CBI}$; (c) rule complexity, this is when integrated FFI take part in explaining complex and abstract language features; (d) communicative value, integrated FFI may help learners practice with features that must be accurate during communication; (e) learners' developmental level; (f) learners' age; (g) language learning aptitude; and $(\mathrm{h})$ learner and teacher's preferences for how to teach and learn about form, which I believe is the most important factor in applying both kinds of FFI. Different preferences from both teachers and students can determine the success of grammar teaching and learning process, as they are the most important elements in the classroom. Students who are used to having isolated FFI may prefer the same method. On the other hand, teachers who are teaching their native language tend to use integrated FFI because of their lack of grammar knowledge. The greatest challenge will then lie in how to bridge the individual preferences of both teachers and learners.

2.5 Teachers Perception on Isolated and Integrated Grammar Teaching

The discussions on how grammar can be taught by different approaches may be the most interesting area in SLA discussion. However, as mentioned by Burgess and Etherington (2002), "it is important that the opinions and experience of teachers themselves are not overlooked" (p. 436). Further, they explain that another essential discussion is related to teachers' perception grammar, as it may greatly impacts their decisions while teaching grammar in language classrooms. 
Burgess and Etherington (2002) examined the beliefs and attitudes of 48 English for Academic Purposes (EAP) teachers towards grammar approaches using a combination of questionnaire and follow up interview. The results revealed that teachers mostly agreed that grammar emphasis in language classrooms is important; however, they expressed great interests in applying the integrated approach in their classrooms. Similar methodology was also used by Borg and Burns (2008), they distributed questionnaires among 176 TESOL teachers from 18 different countries in order to assess "the belief and practices about the integration of grammar and skills teaching" (p. 456). Interestingly, the study also showed that teachers are highly concerned about avoiding isolated grammar approach and attempting to implement the integrated approach in their L2 instructions.

\subsection{Materials/ Instruments}

A questionnaire consisting ten different questions measuring the respondents' view of isolated and integrated grammar teaching was used in order to collect data (see Appendix 1). The items were adapted from a similar study on teachers' perception towards grammar by Burgess and Etherington (2002). Similar to their study, this recent research used a Likert scale "with responses to statements made on a 1-5 scale of agreement" (p. 439).

4.3 Procedure

As a student in the pedagogical grammar class, the researcher was able to know the respondents personally. Therefore, it was not difficult to approach them personally and ask them to fill in the questionnaires. The data from the questionnaire was then transformed into a table showing the frequency of each items as well as its valid percentage.

\section{Research Questions}

The current study investigates the way students who are trained to be teachers of English as a second language perceive the teaching of5. Analysis

at understanding how they

topics in their area of study, second language

the research questions Item

are as follows:

1. Do students of pedagogical grammar class

favor isolated grammar teaching?

grammar class 1

The analysis of this paper is based ongrammar itself. It ain Table 1.actually perceive one of the most controversial

\begin{tabular}{|c|c|c|c|c|c|c|c|c|}
\hline \multirow[t]{2}{*}{$\begin{array}{r}\text { Fred } \\
\text { Number Re }\end{array}$} & $\begin{array}{l}\text { quencyo } \\
\text { pponses }\end{array}$ & of Miss & $\sin \mathrm{Va}$ & \multicolumn{5}{|c|}{ lid Percentagesacquisition. Therefo } \\
\hline & & & \multirow[b]{2}{*}{ Value } & & & & & \\
\hline & & & & & & & & \\
\hline & & & & & & & & \\
\hline & & & & 1234 & 4512 & 345 & & \\
\hline 12 & 11411 & 10201 & $1010 k$ & 402. Do s & studen & ats of & pedagog & cal \\
\hline & & & & & & & & \\
\hline 2001630 & 00106 & $6030 f a$ & avor in & ntegrated & grami & mar t & teaching? & \\
\hline 3104500 & 10040 & 500 & & & & & & \\
\hline $\begin{array}{lllll}40 & 1 & 1 & 1 & 7\end{array} 0$ & $\begin{array}{lll}0 & 10 & 10 \\
0 & 0 & 30\end{array}$ & $\begin{array}{l}1070 \\
4030\end{array}$ & & & & & & \\
\hline 6003430 & $\begin{array}{lll}0 & 0 & 304\end{array}$ & 40304. & 4. Meth & hod & & & & \\
\hline
\end{tabular}

The study was conducted in a small- 800136000103060

scale level, involving students of the Linguistic 9011350010103050

Department of Ohio University. They were 1000325000302050

second year graduate students who were takingTable 1. Results

Pedagogical Grammar class. The course was

conducted twice a week, with an emphasis onThe first two questions aim at

several approaches and strategies to teachunderstanding respondents' general view of

grammar in the context of English as a Foreigngrammar. Surprisingly, only 40 percent of

Language (EFL). There are 27 students comingrespondents agreed that students could learn

from different countries with different experiencegrammar through exposure to language in natural

and background of grammar teaching; however,use. On the other hand, 60 percent of the

the study involved only ten students from therespondent believed that formal instruction helps

class.learners to produce grammatically correct 
language. Thus, it can be inferred that this group of people still believe upon the importance of grammar.

Responses to the next questions (question 3 and 4) contribute in defining teachers' belief of what is needed in their language classrooms. 50 percent of respondent argued that students need a conscious knowledge of grammar in order to improve their language; meanwhile almost 70 percent of respondent strongly agreed that productive practice of structures is a necessary part of the learning process. Here, the integrated communicative approach in teaching grammar seems to be more favorable for this group of future English teachers.

Further, question 5 and 6 were intended to give brief understanding of what is perceived by teachers as the best strategy to improve their students' grammatical performances. The table indicates that 40 percent of respondent agreed that participating in real life tasks with language is the best way for students to develop their grammatical knowledge. At the same time, 40 percent of them also agreed that form-focused correction helps student to improve their grammatical performance. As both questions received the same number of responses, the researcher believes that this group of people would rather combine both approaches. It is also safe to assume that they will not take extreme strategies of either isolated or integrated grammar approach.

Through question 7 and 8, the researcher tried to comprehend what teachers expect from their students when they learn grammar in language classrooms. Only 10 percent of respondents thought that their students would find it difficult to transfer their grammatical knowledge into communicative language use, while 60 percent of them agreed that students would be motivated by communicative strategies for learning grammar. The results showed that teachers assume their students will enjoy a communicative class that exhibits integrated approach grammar teaching more than a class with high emphasis on isolated grammar.

Students' preference of how grammar should be taught is also one of the most important factors that will define the success of grammar teaching, and teachers should be aware of this component as they consider their own preferences. In order to understand teachers' beliefs of their students' preferences, question 9 and question 10 were included in the questionnaire. The result showed that there was no significant difference between both approaches. 50 percent of respondents agreed that students would expect teachers to present grammar point explicitly; and 50 percent of respondents agreed that students would prefer to learn grammar from communicative activities. Consequently, teachers believe that students will favor a combination of both grammar approaches.

6. Conclusion

Second Language Acquisition is a field that is always open for scholarly discussions; apparently, the highlight for the last two years' debate is grammar teaching in the communicative environment. The debate has shifted from whether grammar should be taught or not into what type of grammar can be applied in content-based instructions. And the most recent issue being discussed is how the two types of FFI can be combined.

SLA researchers distinguish two types of $\mathrm{FFI}$, isolated and integrated. Ellis (2006) concludes, "grammar instruction should take the form of separate grammar lessons (a focus-on forms approach) and should also be integrated into communicative activities (a focus on-form approach)" (p.103). Both approaches are mutually useful for developing students' language skills, as they benefit students with different linguistic features depending on several aspects and circumstances. As mentioned before, teachers must consider L1 influence, salience in the input, learners' aptitude and age, and also teachers and learners preferences in order to obtain the best results of using $\mathrm{FFI}$ in the classroom.

Spada and Lightbown (2008) note that there are still continuing debates on this issue; thus, further research needs to be conducted. Ellis (2006) proposes a study that can measure the improvement of students' grammar skills in oral communication as well as record the effect of $\mathrm{FFI}$ within certain range of time. He states, "Iongitudinal studies that employ quantitative as well as qualitative methods will help to show not just if there is a delayed effect for instruction but also its accumulative effect" (p. 103). Meanwhile, Spada and Lightbown (2008) plan to conduct quasi-experimental studies in order to prove that both methods of FFI can be combined. 
Nevertheless, language teachers are expected to be proactive despite the ongoing research, which might not even result in a clear and agreeable solution (Ellis, 2006). Teachers are motivated to find the best method for their own classrooms because they know the dynamics of their classrooms better. Language teachers should enjoy the process of examining "strategies and methodologies that can translate theory into practice" (Nassaji, 2000, p.248). By doing so, teachers are offered the wonderful opportunity to create applicable approaches and techniques for situations specific to their classrooms.

Interestingly, these previous theoretical views from prominent SLA scholars are related with the result of this small-scale study. The result of the recent study has been able to give insights that grammar is still considered important by a group of people that has been trained in a specific course of grammar teaching (pedagogical grammar class). Similar to the result of studies conducted by Burgess and Etherington (2002) and Borg and Burns (2008), this study shows that integrated grammar is perceived to be a more favorable approach by both teachers and students. However, teachers express their intention to combine both isolated and integrated approaches in their future classrooms.

Most of the questions given to the respondents exhibit the idea that isolated and integrated grammar teaching opposes each other. Nevertheless, recognizing the standpoint of a group of people who will be assigned the role of teachers is important, because it suggests how grammar will be taught in future language classrooms.

\section{REFERENCES}

[1] Borg, S., \& Burns, A. (2008). Integrating grammar in adult TESOL classrooms. Applied Linguistics, 29(3), 456-482.

[2] Burgess, J., \&Etherington, S. (2002). Focus on grammatical form: explicit or implicit?.System, 30, 433-458.

Doughty, C., \& Williams, J. (1998). Pedagogical choices in focus on form. In C. Doughty \& J. Williams (Eds.), Focus on form in classroom second language acquisition (pp.197-261). Cambridge: Cambridge University Press.

Ellis, R. (2006). Current issues in the teaching of grammar: An SLA [4] perspective. TESOL Quarterly, 40(1), 83-107. Krashen, S. (1992).Another educator comments.TESOL Quarterly, 26(2), 409-411.

[5] Laufer, B. (2006). Comparing focus on form and focus on forms in second language vocabulary learning. The Canadian Modern

[6] Language Review, 63(1), 149-166.

Long, M. (1991). Focus on form: A design feature in language teaching methodology. In K. DeBot, R. Ginsberg, \& C. Kramsch

[7] (Eds.), Foreign language research in cross-cultural perspective (pp 39-52). Amsterdam: Benjamins.

Nassaji, H. (1999). Towards integrating form-focused instruction and communicative interaction in the second language classroom: Some pedagogical possibilities. The Modern Language Journal, 84(2), 241 -

[8] 250. Retrieved from http://www.jstor.org/stable/330489 Nassaji, H., \&Fotos, S. (2004). Current developments in research on the teaching of grammar.Annual Review of Applied Linguistics, 24, 126-145

[9] Spada, N., \&Lightbown, P. (2008). Form-focused instruction: Isolated or integrated?.TESOL Quarterly, 42(27), 181-207. Retrieved from www.ingentaconnect.com

[10] 